\title{
Implementation of Backpropagation Neural Network to Detect Suspected Lung Disease
}

\author{
${ }^{1}$ Fadhilah Syafria, ${ }^{2}$ Boni Iqbal, ${ }^{3}$ Elvia Budianita, ${ }^{4}$ Iis Afrianty \\ 1,2,3,4 Department of Informatics Engineering, Faculty of Sains and Technology, \\ State Islamic University of Sultan Syarif Kasim Riau \\ Email: ${ }^{1}$ fadhilah.syafria@uin-suska.ac.id, ${ }^{2}$ lboni.iqbal@ @tudents.uin-suska.ac.id, \\ ${ }^{3}$ elvia.budianita@uin-suska.ac.id, ${ }^{4}$ iis.afrianty@uin-suska.ac.id
}

\begin{tabular}{l}
\hline \hline Article Info \\
\hline Article history: \\
Received Dec $14^{\text {th }}, 2017$ \\
Revised Feb $22^{\text {th }}, 2018$ \\
Accepted Mar $25^{\text {th }}, 2018$
\end{tabular}

Keywords:

Artificial Neural Network

Backpropagation

Lung Disease

Early Symptoms

\begin{abstract}
Many People were less concerned with lung health, it caused people identified as suffering from lung diseases. Early symptoms that often appear was cough that took a long time and could be the beginning of more severe disease. Therefore it was necessary to create application that could detect suspected person contracted lung disease. The applications were made by using artificial neural network with Backpropagation with initial input data, symptoms by patients of lung diseases. The symptoms were 22 , and kind of lung diseases as a diagnosis were asthma, pneumonia, pulmonary tuberculosis and lung cancer. It used medical records of lung disease as much as 110 data. Network training uses 3 different architectures [input neurons ; hidden neurons ; output neurons], liked [22; $22 ; 2],[22 ; 33 ; 2]$ and [22; 43 ;2]. Performance measurement was carried out on two types of training data and testing data distribution, namely comparison 90:10 and 80:20. The Parameters values were used namely learning rate $0.1,0.3,0.5,0.7$ and 0.9 . The number of epoch was used, that is 15 epoch, 25 epoch and 35 epoch. Based on the tests performed, it was obtained an accuracy system on the 90:10 data comparison of $82 \%$ and the $80: 20$ data ratio of $82 \%$ as well. Thus, backpropagation method could be applied in detecting suspected lung diseases.
\end{abstract}

Copyright (C) 2018Puzzle Research of Data Technology

\author{
Corresponding Author: \\ Fadhilah Syafria \\ Department of Informatics Engineering \\ Faculty of Sains and Technology \\ State Islamic University of Sultan Syarif Kasim Riau \\ Email: fadhilah.syafria@uin-suska.ac.id
}

\section{PENDAHULUAN}

Paru-paru sebagai pompa satu-satunya untuk sistem pernapasan adalah organ yang sangat penting bagi berlansungnya kehidupan. Namun masih banyak orang yang kurang peduli dengan kesehatan paru-paru, hal ini menyebabkan banyak orang terindikasi menderita penyakit paru-paru, antara lain Tuberculosis (TB), Bronkitis, Penyakit Paru Obstruktif Kronis (PPOK) dan Pneumonia [1]. Penyakit pada paru-paru bisa disebabkan karena bawaan dari lahir dan bisa juga karena faktor atau kebiasaan buruk yang sering dilakukan dalam kehidupan sehari-hari. Kebiasaan buruk yang bisa menyebabkan penyakit pada paru, seperti merokok, minum-minuman beralkohol, menghirup gas karbon terlalu berlebihan, lingkungan yang tidak bersih, dan sebagainya.

Berdasarkan laporan departemen kesehatan tahun 2007, penyakit menular yang menjadi fokus pemerintah dalam menguranginya pada level nasional diantaranya ialah TB dan Infeksi Saluran Pernapasan Akut (ISPA). ISPA sering kali berada pada urutan pertama penyebab kematian pada kelompok bayi dan balita. Selain itu, ISPA juga sering berada dalam daftar 10 penyakit terbanyak di rumah sakit (Depkes,2007). Laporan pederita TB didunia tahun 2006 yang dibuat oleh World Health Organization (WHO) menempatkan Indonesia sebagai penyumbang TB terbesar nomor 3 di dunia setelah India dan Cina dengan jumlah kasus baru sekitar 539.000 dan jumlah kematian sekitar 101.000 pertahun (18,7\%). Dari data South East Asia Medical Center (SEAMIC) Health Statistic 2001 influenza dan pneumonia merupakan penyebab kematian nomor 6 di Indonesia [2]

Tingginya resiko kematian penderita penyakit paru-paru (18.7\%) menunjukkan bahwa penyakit ini perlu ditangani secara serius. Riau merupakan provinsi di Indonesia yang menjadi langganan kabut asap 
setiap tahunnya. Dampak dari kabut asap mengakibatkan kualitas udara di Riau menjadi tercemar. Selain kualitas udara yang buruk, kabut asap juga meningkatkan jumlah dari penderita penyakit paru di Riau. Berdasarkan data yang diperoleh dari UPT. PKK PSDM KOM periode 29 Juni sampai dengan 30 Juli 2015, tercatat 5.033 kasus ISPA, pneunomia 132 kasus, asma 137 kasus, iritasi mata 256 kasus, dan iritasi kulit 546 kasus. Tingginya jumlah penderita penyakit paru saat terjadi kabut asap menunjukkan perlunya perhatian yang serius terhadap Provinsi Riau.

Dalam penanganan penyakit paru-paru dibutuhkan dokter spesialis penyakit paru. Biaya yang dibutuhkan untuk berkonsultasi dengan spesialis paru cukup mahal dan juga tidak setiap daerah terdapat dokter spesialis paru. Oleh sebab itu maka dikembangkan aplikasi dalam mendeteksi dini dugaan penyakit paru-paru berdasarkan gejala-gejalanya untuk dapat membantu masyarakat khususnya Provinsi Riau ataupun yang berkepentingan.

Penelitian mengenai diagnosa penyakit paru telah banyak dilakukan. Salah satunya penelitian yang dilakukan oleh Anggara dan Pramayu (2016) yang meneliti tentang membangun sistem pakar untuk mendiagnosa penyakit paru menggunakan teorema bayes. Penelitian tersebut berhasil membangun sebuah sistem pakar yang mampu mendiagnosa penyakit paru-paru beserta nilai probabilitas dari penyakit. Akurasi yang dihasilkan oleh sistem sebesar 85\% [3]. Selanjutnya penelitian lain yang dilakukan oleh Rahmawati dalam mendiagnosis penyakit paru-paru menggunakan metode foward chaining. Dari hasil pengujian validitas sistem, diperoleh nilai probabilitas keakuratan sistem sebesar $84.21 \%$ dan ketidakakuratan sistem sebesar $15.79 \%$ [4].

Berdasarkan penelitian di atas, maka dapat dibuat suatu penelitian lain dalam mendeteksi dugaan penyakit paru dengan menggunakan konsep jaringan syaraf tiruan. Penggunaan jaringan syaraf tiruan dinilai baik untuk mendeteksi suatu penyakit [5]. Penelitian tersebut menyimpulkan bahwa jaringan syaraf tiruan memiliki 3 keunggulan dalam mendeteksi suatu penyakit diantaranya, kemampuan dalam mengolah data dengan jumlah yang besar, meningkatkan kemungkinan dalam menemukan data yang saling berhubungan dan mempersingkat waktu diagnosis.

Jaringan syaraf tiruan merupakan salah satu representasi buatan dari otak manusia yang selalu mencoba untuk mensimulasikan proses pembelajaran pada otak manusia tersebut [6]. Istilah buatan digunakan karena jaringan syaraf ini diimplementasikan dengan menggunakan program komputer yang mampu menyelesaikan sejumlah proses perhitungan selama proses pembelajaran [7]. Salah satu metode pada jaringan syaraf tiruan adalah Metode Backpropagation.

Berbagai penelitian pada bidang jaringan syaraf tiruan dengan menggunakan Backpropagation telah dilakukan sebelumnya, yaitu penelitian oleh Yuwono dan Rustamaji (2011) [8]. Penelitian ini membahas tentang diagnosa gangguan saluran pernapasan dengan menggunakan Backpropagation. Arsitektur jaringan syaraf tiruan menggunakan 10 variabel masukan, 1 lapisan tersembunyi dengan 10 neuron, dan 5 kelas keluaran (asma, bronkhitis, pneumonia, pneumotoraks dan sarkoidosis). Hasil penelitian menunjukkan bahwa backpropagation berhasil mendignosa gangguan saluran pernapasan dengan tingkat pengenalan $90 \%$. Penelitian lainnya oleh Ratnaningtyas dan Dwijanto (2013) yang melakukan penelitian mengenai pendeteksian penyakit TB menggunakan backpropagation[9]. Dalam penelitian ini hanya membahas salah satu penyakit paru-paru yaitu penyakit TB. Hasil dari penelitian ini memberikan tingkat akurasi $100 \%$.

Berdasarkan penelitian-penelitian di atas, maka dapat diambil suatu rumusan dengan membangun sebuah sistem jaringan syaraf tiruan dengan menggunakan metode backpropagation untuk mendeteksi dugaan penyakit paru-paru. Melihat akurasi yang dihasilkan oleh metode backpropagation dalam mendeteksi suatu penyakit sangat tinggi hingga mencapai 100\%, maka penelitian ini dibangun menggunakan jaringan syaraf tiruan dengan judul "Implementasi Jaringan Syaraf Tiruan Backpropagation untuk Mendeteksi Dugaan Penyakit Paru”.

\section{DATA DAN METODE}

\subsection{Data}

Data yang digunakan pada penenlitian ini adalah data rekam medis pasien penyakit paru di Rumah Sakit Umum Daerah (RSUD) Arifin Ahmad. Pengambilan data di RSUD melalui beberapa tahapan diantaranya dinyatakan lulus tes kode etik kedokteran yang diuji lansung oleh dosen kedokteran Universitas Riau. Setelah lulus peneliti diizinkan mengambil data lansung ke ruangan rekam medik RSUD. Data yang diambil berjumlah 110 data. Data rekam medis tersebut terdiri dari 22 gejala masukan (Tabel 1) dan 4 kelas keluaran (Asma, Pneumonia, TB Paru, Kanker Paru-paru). Berikut gejala yang digunakan dapat dilihat pada Tabel 1.

Tabel 1. Variabel masukan

\begin{tabular}{cl}
\hline Variabel & \multicolumn{1}{c}{ Nama Variabel } \\
\hline $\mathrm{X} 1$ & Demam \\
$\mathrm{X} 2$ & Demam lebih dari seminggu \\
\hline
\end{tabular}

Implementation of Backpropagation Neural Network... (Syafria et al.) 


\begin{tabular}{cl}
\hline Variabel & \multicolumn{1}{c}{ Nama Variabel } \\
\hline X3 & Demam naik turun \\
X4 & Nafsu makan turun \\
X5 & Batuk \\
X6 & Batuk berdahak \\
X7 & Batuk lebih dari 2 minggu \\
X8 & Batuk darah \\
X9 & Dada nyeri \\
X10 & Mual \\
X11 & Muntah \\
X12 & Sakit kepala \\
X13 & Sakit punggung \\
X14 & Keringat malam \\
X15 & Badan lemah \\
X16 & Riwayat asma \\
X17 & Riwayat kanker paru-paru \\
X18 & Sesak napas \\
X19 & Sesak napas lebih dari seminggu \\
X20 & Mengi \\
X21 & Demam tinggi \\
X22 & Demam sore dan malam \\
\hline
\end{tabular}

\subsection{Pembagian Data}

Data yang digunakan pada penelitian dibagi menjadi 2 bagian data, yaitu: data latih (training) dan data uji (testing). Total data yang digunakan adalah 110 data yang terdiri dari, 30 data penyakit asma, 30 data penyakit pneumonia, 20 data penyakit TB-Paru dan 30 data penyakit kanker paru. Total data tadi dibagi kedalam 2 pengujian dengan perbandingan data latih banding data uji, $90: 10$ dan $80: 20$.

\subsection{Normalisasi}

Data yang telah dikumpulkan kemudian dilakukan tahap normalisasi data. Data masukan penelitian ini terdiri dari masukan "ya" atau "tidak" mengalami gejala penyakit paru. Nilai dari masukan "ya" adalah 1, dan nilai dari masukan "tidak" adalah 0. Tujuan dari normalisasi data masukan dan target yaitu untuk mentranformasi data agar data dapat diproses oleh metode backpropagation yang menggunakan fungsi aktivasi sigmoid biner dengan rentang nilai 0 sampai dengan 1. Contoh normalisasi dapat dilihat pada Tabel 2.

Tabel 2. Data rekam medis pasien penyakit paru-paru

\begin{tabular}{|c|c|c|c|c|c|c|c|c|c|}
\hline \multirow{2}{*}{ No } & \multirow{2}{*}{ Variabel } & \multicolumn{4}{|c|}{ Data Pasien (P) Sebelum Normalisasi } & \multicolumn{4}{|c|}{ Data Pasien (P) Setelah Normalisasi } \\
\hline & & $\mathrm{P} 1$ & $\mathrm{P} 2$ & P3 & $\mathrm{P} 4$ & $\mathrm{P} 1$ & $\mathrm{P} 2$ & P3 & $\mathrm{P} 4$ \\
\hline 1 & $\mathrm{X}_{1}$ & Tidak & $\mathrm{Ya}$ & Tidak & Tidak & 0 & 1 & 0 & 0 \\
\hline 2 & $\mathrm{X}_{2}$ & Tidak & Tidak & Tidak & Tidak & 0 & 0 & 0 & 0 \\
\hline 3 & $\mathrm{X}_{3}$ & Tidak & $\mathrm{Ya}$ & Tidak & Tidak & 0 & 1 & 0 & 0 \\
\hline 4 & $\mathrm{X}_{4}$ & Tidak & $\mathrm{Ya}$ & Ya & $\mathrm{Ya}$ & 0 & 1 & 1 & 1 \\
\hline 5 & $\mathrm{X}_{5}$ & Ya & Tidak & Tidak & Tidak & 1 & 0 & 0 & 0 \\
\hline 6 & $X_{6}$ & Tidak & $\mathrm{Ya}$ & $\mathrm{Ya}$ & Tidak & 0 & 1 & 1 & 0 \\
\hline 7 & $X_{7}$ & Tidak & Tidak & $\mathrm{Ya}$ & Tidak & 0 & 0 & 1 & 0 \\
\hline 8 & $\mathrm{X}_{8}$ & Tidak & Tidak & Tidak & $\mathrm{Ya}$ & 0 & 0 & 0 & 1 \\
\hline 9 & $\mathrm{X}_{9}$ & Tidak & Tidak & $\mathrm{Ya}$ & $\mathrm{Ya}$ & 0 & 0 & 1 & 1 \\
\hline 10 & $\mathrm{X}_{10}$ & Tidak & Tidak & Tidak & Tidak & 0 & 0 & 0 & 0 \\
\hline 11 & $X_{11}$ & Tidak & $\mathrm{Ya}$ & Tidak & Tidak & 0 & 1 & 0 & 0 \\
\hline 12 & $X_{12}$ & Tidak & $\mathrm{Ya}$ & Tidak & Tidak & 0 & 1 & 0 & 0 \\
\hline 13 & $X_{13}$ & Tidak & Tidak & Tidak & $\mathrm{Ya}$ & 0 & 0 & 0 & 1 \\
\hline 14 & $\mathrm{X}_{14}$ & Tidak & Tidak & Tidak & Tidak & 0 & 0 & 0 & 0 \\
\hline 15 & $\mathrm{X}_{15}$ & Tidak & Tidak & $\mathrm{Ya}$ & Tidak & 0 & 0 & 1 & 0 \\
\hline 16 & $\mathrm{X}_{16}$ & $\mathrm{Ya}$ & Tidak & Tidak & Tidak & 1 & 0 & 0 & 0 \\
\hline 17 & $X_{17}$ & Tidak & Tidak & Tidak & $\mathrm{Ya}$ & 0 & 0 & 0 & 1 \\
\hline 18 & $\mathrm{X}_{18}$ & $\mathrm{Ya}$ & $\mathrm{Ya}$ & $\mathrm{Ya}$ & $\mathrm{Ya}$ & 1 & 1 & 1 & 1 \\
\hline 19 & $\mathrm{X}_{19}$ & Tidak & Tidak & Tidak & Tidak & 0 & 0 & 0 & 0 \\
\hline 20 & $X_{20}$ & $\mathrm{Ya}$ & Tidak & Tidak & $\mathrm{Ya}$ & 1 & 0 & 0 & 1 \\
\hline 21 & $\mathrm{X}_{21}$ & Tidak & $\mathrm{Ya}$ & Tidak & Tidak & 0 & 1 & 0 & 0 \\
\hline 22 & $X_{22}$ & Tidak & Tidak & Tidak & $\mathrm{Ya}$ & 0 & 0 & 0 & 1 \\
\hline
\end{tabular}

\subsection{Arsitektur Backpropagation}

Data masukan sebanyak 22 dijadikan dasar dalam menentukan banyak neuron pada input layer sedangkan dalam menentukan banyaknya neuron pada hidden layer maka dihitung berdasarkan Persamaan 1 berikut [10] dikutip oleh Afrianty, Nasien, Kadir, dan Haron [11].

$$
l \leq m<2 l
$$


Dimana $l$ adalah jumlah inputan, $m$ adalah jumlah hidden layer dan $2 l$ adalah 2 kali jumlah inputan. Artinya jumlah neuron pada hidden layer berjumlah minimal 22 dan maksimal 44. Neuron output berjumlah 2 neuron, karena pada penenlitian ini menggunakan fungsi aktifasi sigmoid biner.

Setelah ditentukan variabel masukan, neuron pada hidden layer dan target, maka dapat dibentuk arsitektur JST backpropagation. Pada penelitian ini sistem dibangun dengan menggunakan 3 arsitektur JST [neuron input ; neuron hidden ; neuron output], yaitu JST dengan [22;22;2], [22; $33 ; 2]$ dan [22; $43 ; 2]$. Arsitektur JST dengan [22; 22 ; 2]yang akan dibangun dapat dilihat pada Gambar 1.

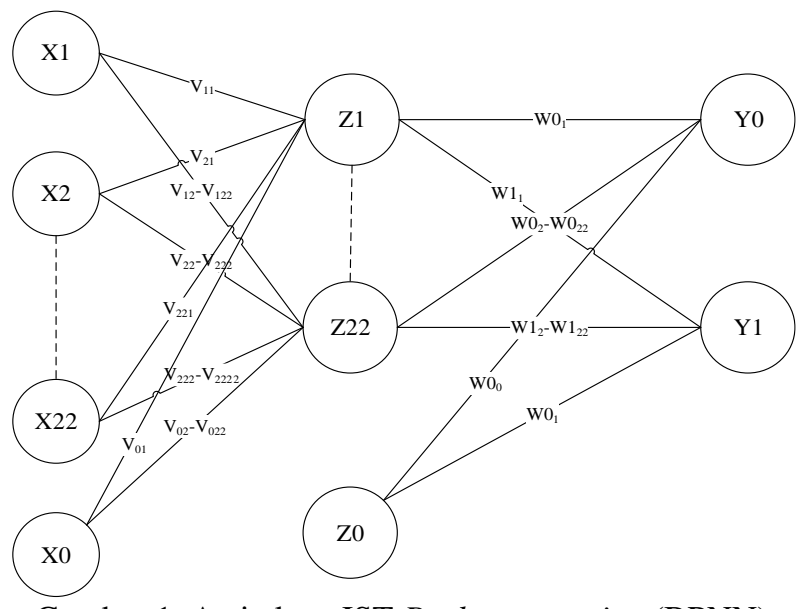

Gambar 1. Arsitektur JST Backpropagation (BPNN)

Dengan $\mathrm{X}$ adalah masukan (input), $\mathrm{V}$ adalah bobot pada hidden layer, $\mathrm{W}$ adalah bobot pada output layer, $\mathrm{Z}$ adalah Hidden layer, $\mathrm{Y}$ adalah output layer, $\mathrm{X} 0$ adalah bias ke hidden layer dan $\mathrm{Z} 0$ adalah bias ke output layer

\subsection{Algoritma Backpropagation}

Secara rinci algoritma pelatihan jaringan backpropagation dapat diuraikan dengan langkah-langkah sebagai berikut [12]:

(1) Inisialisasi bobot, konstanta learning rate (a), toleransi error atau nilai bobot (jika menggunakan nilai bobot sebagai kondisi berhenti) atau set maksimal epoch (jika menggunakan banyaknya epoch sebagai kondisi berhenti).

(2) Selama kondisi berhenti belum tercapai, lakukan langkah (3) sampai (8).

Tahap Perambatan Maju (Feedforward):

(3) Setiap unit input (x) (Xi, i=1,2,3, ., n) menerima sinyal dan meneruskan sinyal kesemua unit pada lapisan tersembunyi.

(4) Setiap unit lapisan tersembunyi (z) $(\mathrm{Zj}, \mathrm{j}=1,2,3, \ldots, \mathrm{p})$ akan menjumlahkan sinyal-sinyal input yang telah memiliki bobot dengan Persamaan 2.

$$
Z_{-} i n j=V_{0 \mathrm{j}}+\sum x_{\mathrm{i}} \nu_{\mathrm{ij}}
$$

Untuk menghitung sinyal output, perlu menggunakan fungsi aktivasi sigmoid biner (Persamaan 3).

$$
z j=f\left(z \_ \text {in } j\right)
$$

Hasil dari sinyal output (zj) akan dikirimkan kesemua unit-unit output.

(4) Setiap unit output (y) ( $\mathrm{Yk}, \mathrm{k}=1,2,3, \ldots, \mathrm{m})$ menjumlahkan sinyal-sinyal input terbobot (y_ink) (Persamaan 4)

$$
y_{-} i n \mathrm{k}=w 0 \mathrm{k}+\sum Z \mathrm{i} W \mathrm{jk}
$$

Menggunakan fungsi aktivasi sigmoid biner untuk menghitung sinyal output yang teraktivasi (yk) (Persamaan 5). 


$$
y \mathrm{k}=\mathrm{f}\left(\mathrm{y} \_ \text {ink }\right)
$$

Kirimkan sinyal tersebut ke semua unit dilapisan unit-unit output backpropagation.

Tahap Perambatan Mundur (Backpropagation) :

(5) Setiap unit output (Y) ((Y) () $\mathrm{k}, \mathrm{k}-1,2,3, \ldots, \mathrm{m})$ menerima target pola yang berhubungan dengan pola input pembelajaran, hitung informasi erornya (Persamaan 6)

$$
\delta \mathrm{k}=(\mathrm{tk}-\mathrm{yk}) f^{\prime}\left(\mathrm{y} \_ \text {ink }\right)
$$

Kemudian hitung kembali koreksi bobot (untuk memperbaiki nilai wjk) dengan Persamaan 7.

$$
\Delta w j k=\alpha \delta \mathrm{k} \mathrm{zj}
$$

dan menghitung nilai koreksi bias (untuk memperbaiki nilai wok) dengan Persamaan 8.

$$
\Delta w 0 k=\alpha \delta \mathrm{k}
$$

Kirimkan $\delta$ k ini ke unit-unit yang ada di lapisan bawahnya.

(6) Tiap-tiap unit tersembunyi $(\mathrm{Zj}, \mathrm{j}=1,2,3, \ldots, \mathrm{p})$ menjumlahkan delta input dari unit-unit yang berada pada lapisan diatasnya (Persamaan 9).

$$
\delta \_i n \mathrm{j}=\Sigma \delta \mathrm{k} . w \mathrm{jk}
$$

Kalikan nilai ini dengan turunan dari fungsi aktivasinya untuk menhitung informasi error (Persamaan 10).

$$
\delta \mathrm{j}=\delta \_ \text {inj } f^{\prime}\left(\mathrm{z} \_ \text {inj }\right)
$$

Kemudian hitung koreksi bobot yang digunakan untuk memperbaiki nilai vjk (Persamaan 11).

$$
\Delta v \mathrm{jk}=\alpha \delta \mathrm{j} \mathrm{xi}
$$

Hitung juga koreksi bobot bias akan digunakan untuk memperbaiki nilai voj (Persamaan 12).

$$
\Delta v 0 \mathrm{j}=\alpha \delta \mathrm{j}
$$

\section{Tahap Perubahan Bobot dan Bias}

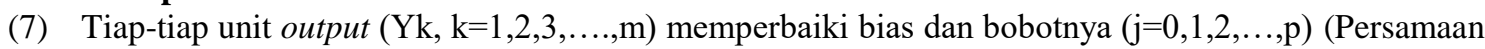
13).

$$
w \mathrm{jk}(\text { baru })=w \mathrm{jk}(\operatorname{lama})+\Delta w \mathrm{jk}
$$

Tiap-tiap unit tersembunyi $(\mathrm{Zj}, \mathrm{k}=1,2,3, \ldots, \mathrm{p})$ memperbaiki bias dan bobotnya $(\mathrm{i}=0,1,2,3, \ldots, \mathrm{n})$ (Persamaan 14).

$$
v \mathrm{ij}(\text { baru })=v \mathrm{ij}(\text { lama })+\Delta v \mathrm{ij}
$$

(8) Tes kondisi berhenti.

\subsection{Pelatihan dan Pengujian}

Tahapan pertama yang harus dilakukan pada proses pelatihan ialah menginisialisasikan bobot awal dengan bilangan kecil secara acak serta menetapkan konfigurasi jaringan syaraf tiruan yang akan digunakan. Konfigurasi yang dimaksud ialah jumlah dari epoch dan besarnya nilai learning rate. Selanjutnya memasukkan data yang akan dilatih lalu data tersebut masuk ke dalam fase perambatan maju (feedforward) lalu fase perambatan mundur(backpropagation) dan terakhir adalah fase peng-update-an bobot dan bias. Proses ini akan dilakukan berulang kali sampai mendapatkan bobot dengan error minimal yang kecil atau 
epoch yang ditentukan telah terpenuhi.Pada akhir proses pelatihan akan diperoleh bobot dan bias akhir yang akan disimpan untuk digunakan pada tahap pengujian.

Setelah data selesai dilatih maka proses selanjutnya ialah melakukan proses pengujian. Pada proses ini bobot yang digunakan ialah bobot baru hasil dari pelatihan. Untuk mendapatkan akurasi dari pengujian maka digunakan confusion matrix. Confusion matrix adalah sebuah tabel yang menyatakan jumlah data uji yang benar diklasifikasikan dan jumlah data uji yang salah diklasifikasikan [13]. Confution matrix akan digunakan dalam mengukur akurasi dari sistem deteksi dugaan penyakit paru. Contoh confusion matrix untuk klasifikasi biner ditunjukkan pada Tabel 3.

Table 3. Confusion matrix

\begin{tabular}{cccc}
\hline & & \multicolumn{2}{c}{ Kelas Prediksi } \\
\cline { 3 - 4 } Kelas & 1 & 1 & 0 \\
Sebenarnya & 0 & TP & FN \\
\hline
\end{tabular}

Keterangan:

(1) True Positive (TP), yaitu jumlah dokumen dari kelas 1 yang benar diklasifikasikan sebagai kelas 1.

(2) True Negative (TN), yaitu jumlah dokumen dari kelas 0 yang benar diklasifikasikan sebagai kelas 0 .

(3) False Positive (FP), yaitu jumlah dokumen dari kelas 0 yang salah diklasifikasikan sebagai kelas 1.

(4) False Negative (FN), yaitu jumlah dokumen dari kelas 1 yang salah diklasifikasikan sebagai kelas 0.

Perhitungan akurasi dinyatakan dalam Persamaan 15.

$$
\text { Akurasi }=\frac{T P+T N}{T P+F N+F P+T N} \times 100 \%
$$

\section{HASIL DAN PEMBAHASAN}

Sistem deteksi dugaan penyakit paru yang dibangun diimplementasikan menggunkan bahasa pemrograman PHP dan database MySQL. User pada sistem terdiri dari 2 level yaitu, administrator dan umum. Pada sistem deteksi dugaan penyakit paru terdiri dari 2 proses utama, yaitu proses pelatihan dan proses pengujian. Gambar 2 adalah tampilan menu pelatihan.

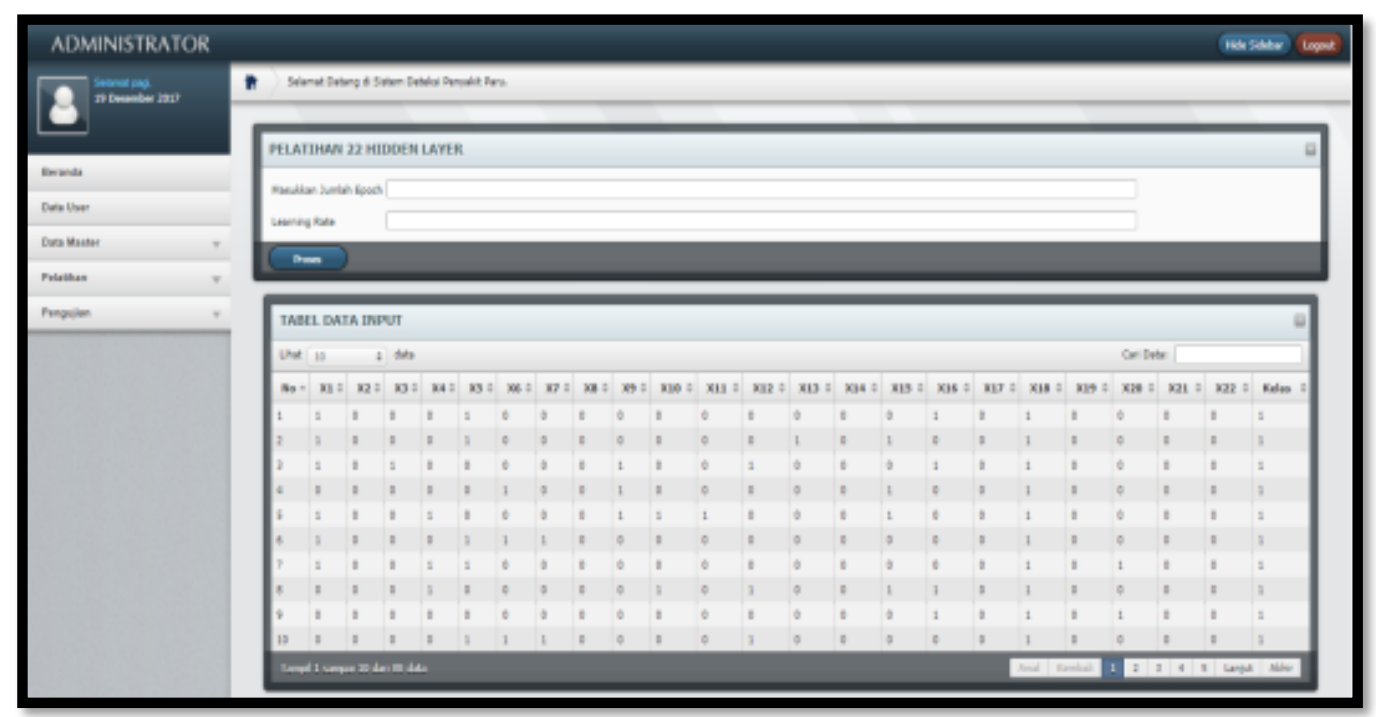

Gambar 2. Menu pelatihan

Pada menu pelatihan terdapat 2 field yang harus diisi terlebih dahulu yaitu jumlah epoch dan learning rate. Setelah proses pelatihan selesai dilakukan, dilanjutkan dengan proses pengujian. Proses ini bertujuan untuk mengetahui hasil dari deteksi dugaan penyakit paru. Gambar 3 merupakan tampilan menu pengujian. Pada menu pengujian terdapat pilihan gejala yang dipilih sesuai dengan gejala yang diderita. Gambar 4 merupakan tampilan dari hasil pengujian berupa dugaan penyakit yang diderita oleh pasien. 


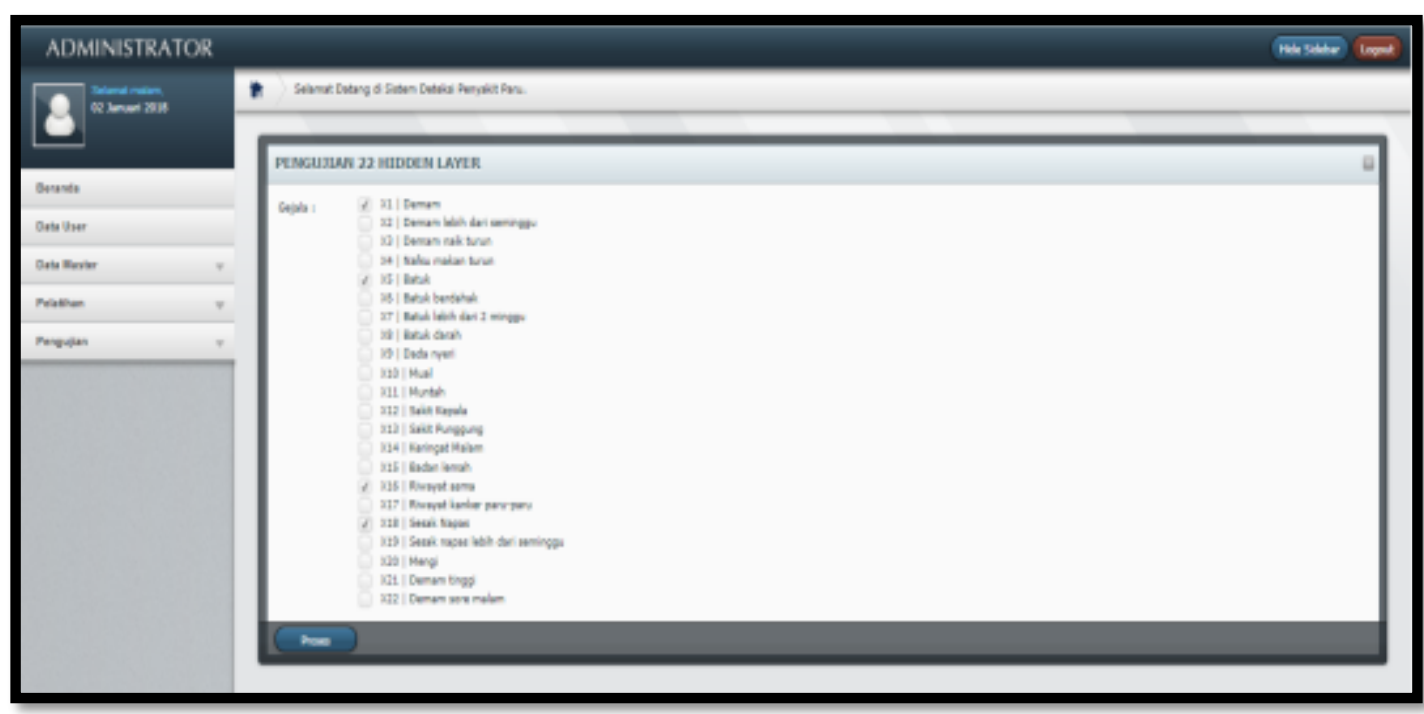

Gambar 3. Menu pengujian

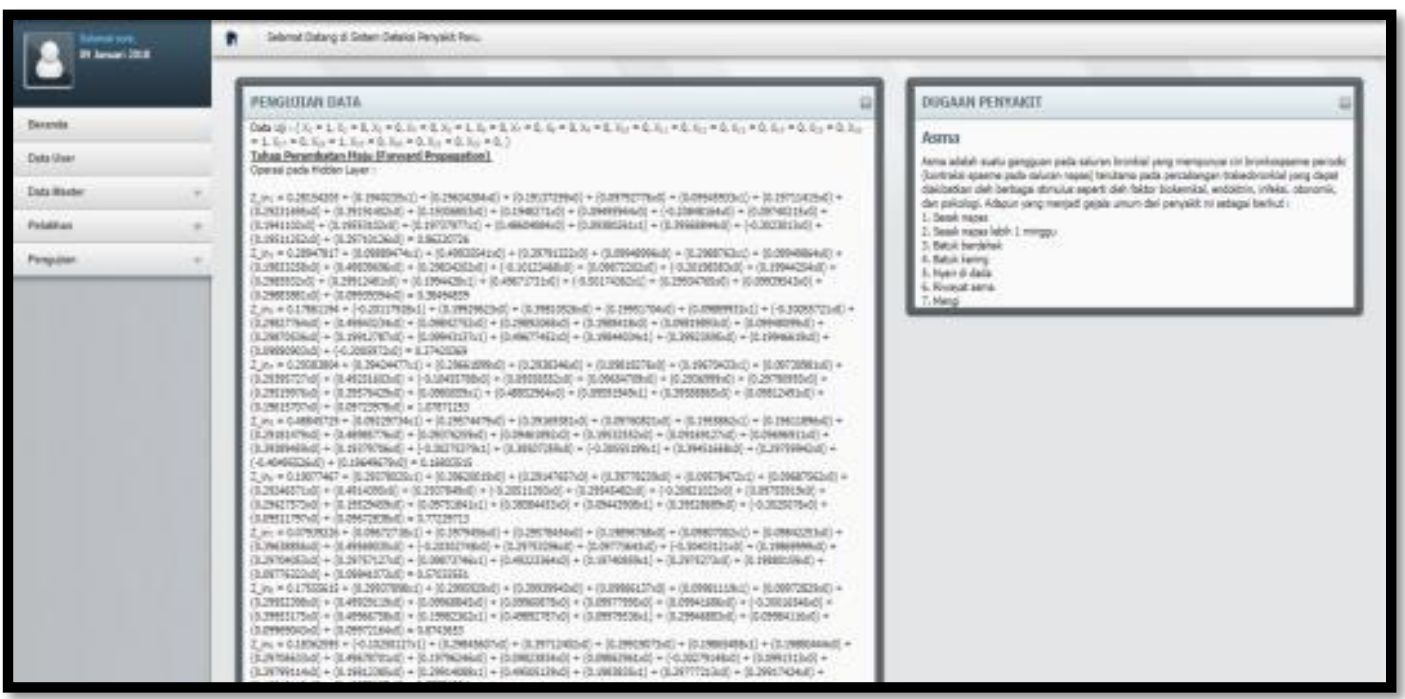

Gambar 4. Hasil pengujian

Performa metode Backpropagation pada sistem deteksi dugaan penyakit paru disajikan dalam Tabel 4 dan Tabel 5. Pengujian performa sistem dilakukan dengan mengganti-ganti beberapa parameter, yaitu learning rate, jumlah neuron pada hidden layer, jumlah epoch dan perbandingan jumlah data latih dan data uji. Untuk nilai learning rate yang digunakan yaitu $0.1,0.3,0.5,0.7$, dan 0.9 , jumlah neuron hidden layer yang digunakan yaitu 22, 33 dan 43, dan perbandingan jumlah data latih dan data uji yang digunakan adalah 90:10 dan 80:20.

Tabel 4. Hasil pengujian pada perbandingan data 90:10

\begin{tabular}{|c|c|c|c|c|c|}
\hline No & $\alpha$ & Epoch & $\begin{array}{l}\text { Hidden } \\
22\end{array}$ & $\begin{array}{c}\text { Hidden } \\
\mathbf{3 3}\end{array}$ & $\begin{array}{c}\text { Hidden } \\
43\end{array}$ \\
\hline \multirow{3}{*}{1} & \multirow{3}{*}{0.1} & 15 & $82 \%$ & $27 \%$ & $82 \%$ \\
\hline & & 25 & $64 \%$ & $82 \%$ & $64 \%$ \\
\hline & & 35 & $54 \%$ & $54 \%$ & $64 \%$ \\
\hline \multirow{3}{*}{2} & \multirow{3}{*}{0.3} & 15 & $73 \%$ & $54 \%$ & $64 \%$ \\
\hline & & 25 & $73 \%$ & $82 \%$ & $82 \%$ \\
\hline & & 35 & $27 \%$ & $64 \%$ & $54 \%$ \\
\hline \multirow{3}{*}{3} & \multirow{3}{*}{0.5} & 15 & $73 \%$ & $54 \%$ & $45 \%$ \\
\hline & & 25 & $27 \%$ & $82 \%$ & $73 \%$ \\
\hline & & 35 & $27 \%$ & $64 \%$ & $82 \%$ \\
\hline \multirow{2}{*}{4} & \multirow{2}{*}{0.7} & 15 & $27 \%$ & $54 \%$ & $82 \%$ \\
\hline & & 25 & $27 \%$ & $82 \%$ & $54 \%$ \\
\hline
\end{tabular}




\begin{tabular}{cccccc}
\hline \multirow{2}{*}{ No } & \multirow{2}{*}{$\boldsymbol{\alpha}$} & Epoch & $\begin{array}{c}\text { Hidden } \\
\mathbf{2 2}\end{array}$ & $\begin{array}{c}\text { Hidden } \\
\mathbf{3 3}\end{array}$ & $\begin{array}{c}\text { Hidden } \\
\mathbf{4 3}\end{array}$ \\
& & 35 & $73 \%$ & $64 \%$ & $64 \%$ \\
\hline & & 15 & $27 \%$ & $54 \%$ & $82 \%$ \\
5 & 25 & $73 \%$ & $82 \%$ & $73 \%$ \\
& \multirow{3}{*}{0.9} & 35 & $54 \%$ & $73 \%$ & $73 \%$ \\
\hline
\end{tabular}

Berdasarkan pengujian dengan perbandingan 90:10 menghasilkan akurasi tertinggi 82\% menggunakan 22 hidden layer, 82\% menggunakan dan 82\% menggunakan 43 hidden layer. Pengujian dilakukan dengan menggunakan kombinasi nilai learning rate dan jumlah epoch mulai dari yang terkecil sampai yang terbesar.

Tabel 5. Hasil pengujian pada perbandingan data 80:10

\begin{tabular}{|c|c|c|c|c|c|}
\hline No & $\alpha$ & Epoch & $\begin{array}{c}\text { Hidden } \\
22\end{array}$ & $\begin{array}{c}\text { Hidden } \\
33\end{array}$ & $\begin{array}{c}\text { Hidden } \\
43\end{array}$ \\
\hline \multirow{3}{*}{1} & \multirow{3}{*}{0.1} & 15 & $63 \%$ & $27 \%$ & $36 \%$ \\
\hline & & 25 & $63 \%$ & $27 \%$ & $45 \%$ \\
\hline & & 35 & $68 \%$ & $77 \%$ & $77 \%$ \\
\hline \multirow{3}{*}{2} & \multirow{3}{*}{0.3} & 15 & $68 \%$ & $45 \%$ & $45 \%$ \\
\hline & & 25 & $56 \%$ & $77 \%$ & $77 \%$ \\
\hline & & 35 & $41 \%$ & $45 \%$ & $68 \%$ \\
\hline \multirow{3}{*}{3} & \multirow{3}{*}{0.5} & 15 & $59 \%$ & $45 \%$ & $77 \%$ \\
\hline & & 25 & $22 \%$ & $77 \%$ & $54 \%$ \\
\hline & & 35 & $27 \%$ & $59 \%$ & $54 \%$ \\
\hline \multirow{3}{*}{4} & \multirow{3}{*}{0.7} & 15 & $27 \%$ & $27 \%$ & $36 \%$ \\
\hline & & 25 & $27 \%$ & $68 \%$ & $54 \%$ \\
\hline & & 35 & $54 \%$ & $77 \%$ & $64 \%$ \\
\hline \multirow{3}{*}{5} & \multirow{3}{*}{0.9} & 15 & $27 \%$ & $54 \%$ & $82 \%$ \\
\hline & & 25 & $27 \%$ & $77 \%$ & $73 \%$ \\
\hline & & 35 & $63 \%$ & $63 \%$ & $73 \%$ \\
\hline
\end{tabular}

Berdasarkan pengujian dengan perbandingan 80:20 menghasilkan akurasi tertinggi $68 \%$ menggunakan 22 hidden layer, 77\% menggunakan 33 hidden layer dan 82\% menggunakan 43 hidden layer. Pengujian dilakukan dengan menggunakan kombinasi nilai learning rate dan jumlah epoch mulai dari yang terkecil sampai yang terbesar.

\section{KESIMPULAN}

Berdarkan hasil yang diperoleh pada penelitian ini, terdapat beberapa kesimpulan yang disajikan sebagai berikut:

(1) Backpropagation dapat diterapkan untuk aplikasi dugaan penyakit paru-paru, dibuktikan dengan akurasi yang dihasilkan pada pengujian.

(2) Parameter yang digunakan pada penelitian yaitu learning rate $0.1,0.3,0.5$, 0.7, dan 0.9, jumlah epoch sebanyak 15 epoch, 25 epoch dan 35 epoch dan menggunakan 3 arsitektur jaringan yang berbeda, yaitu [22:22:2]; [22:33:2] dan [22:43:2]. Pelatihan menggunakan pembagian data latih dan data uji dengan perbandingan 90:10 dan 80:20. Akurasi tertinggi yang didapat selama pengujian pada pembagian data $90: 10$ sebesar $82 \%$ dan pembagian data 80:20 sebesar $82 \%$.

(3) Jumlah neuron hidden layer berpengaruh terhadap akurasi pengenalan. Pengaruhnya akan terlihat ketika menggunakan jumlah data latih yang sedikit yaitu pada perbandingan data latih dan data uji 80:20, sedangkan untuk data latih yang lebih besar yaitu 90:10 akurasinya tetap walaupun jumlah neuron hidden layer nya berubah.

(4) Nilai learning rate dan jumlah epoch juga berpengaruh terhadap akurasi pengenalan terlihat pada Tabel 4 dan Tabel 5, dimana akurasi berubah-ubah ketika nilai parameter diubah-ubah.

\section{REFERENSI}

[1] I. Junaidi, "Penyakit Paru \& Saluran Napas," in PT Bhuana Ilmu Populer, vol. 1, no. 2, Jakarta: Bhuana Ilmu Popular, 2010, pp. 75-81.

[2] M. Yunus and S. Setyowibowo, "Aplikasi sistem pendukung keputusan diagnosa penyakit paru- paru dengan metode forward chaining," vol. 2, no. 2, pp. 95-114, 2011.

[3] A. W. Ganda Anggara, Gede Pramayu, "Membangun sistem pakar menggunakan teorema bayes untuk mendiagnosa penyakit paru-paru," Semin. Nas. Teknol. Inf. dan Multimed. 2016, pp. 79-84, 2016.

[4] E. Rahmawati, "Sistem Pakar Diagnosis Penyakit Paru-Paru Menggunakan Metode Forward Chaining," J. Tek. Elektro, vol. 8, no. 2, 2016. 
[5] F. Amato, A. López, E. M. Peña-méndez, P. Vaňhara, and A. Hampl, “Artificial neural networks in medical diagnosis," pp. 47-58, 2013.

[6] S. Kusumadewi and S. Hartati, "Neuro-Fuzzy: Integrasi Sistem Fuzzy dan Jaringan Syaraf," in Yogyakarta: Graha Ilmu, 2nd ed., Yogayakarta: Graha Ilmu, 2006.

[7] L. V Fausett, Fundamentals of neural networks. Prentice-Hall, 1994.

[8] U. D. Bambang Yuwono, Heru Cahya Rustamaji, "Diagnosa gangguan saluran pernafasan menggunakan jaringan syaraf tiruan," semnasIF, vol. 2011, no. semnasIF, pp. 27-34, 2011.

[9] E. S. Ratnaningtyas Widyani Purnamasari, Dwijanto, "Implementasi Jaringan Syaraf Tiruan Backpropagation Sebagai Sistem Deteksi Penyakit Tuberculosis (TBC),” vol. 2, no. 2, pp. 0-6, 2013.

[10] G. . Rajasekaran, S., Vijayalaksmi, Neural Networks, Fuzzy Logic, Genetic Algorithms, Synthesis and Applications. New Delhi: Prentice-Hall of India, 2007

[11] I. Afrianty, D. Nasien, M. R. A. Kadir, and H. Haron, "Backpropagation neural network for sex determination from patella in forensic anthropology," Lect. Notes Electr. Eng., vol. 279 LNEE, 2014.

[12] Sri, K. 2003. Artificial Intelligence (Teknik dan Aplikasinya). Graha Ilmu. Yogyakarta.

[13] A. Indriani, "Klasifikasi Data Forum dengan menggunakan Metode Naïve Bayes Classifier," Semin. Nas. Apl. Teknol. Inf., pp. 5-10, 2014

\section{BIBLIOGRAFIPENULIS}
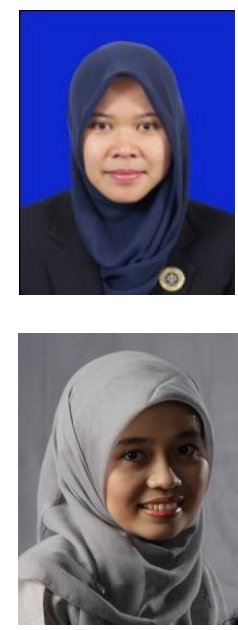

Penulis adalah pengajar di Jurusan Teknik Informatika Universitas Islam Negeri Sultan Syarif Kasim (UIN Suska) Riau. Selain itu, penulis juga tergabung di kelompok keilmuan Ilmu Komputer, FST UIN SUSKA Riau

Penulis adalah pengajar di Jurusan Teknik Informatika Universitas Islam Negeri Sultan Syarif Kasim (UIN Suska) Riau. Selain itu, penulis juga tergabung di kelompok keilmuan Ilmu Komputer, FST UIN SUSKA Riau

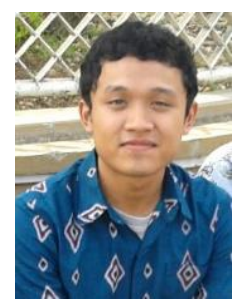

Penulis adalah mahasiswa $\mathrm{S} 1$ Teknik Informatika UIN Sultan Syarif Kasim Riau

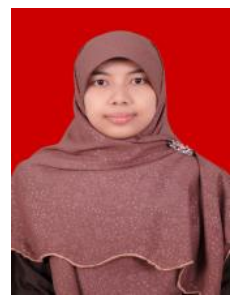

Penulis adalah pengajar di Jurusan Teknik Informatika Universitas Islam Negeri Sultan Syarif Kasim (UIN Suska) Riau. Selain itu, penulis juga tergabung di kelompok keilmuan Ilmu Komputer, FST UIN Suska Riau 